\title{
Manipulation of growth of the Amazonian fish tambaqui, Colossoma macropomum (Characiformes: Serrasalmidae): analysis of physiological and zootechnical aspects
}

\author{
Arlan de Lima PAZ ${ }^{1,2^{*}}$, Adalberto Luis VAL ${ }^{1,2}$ \\ Instituto Nacional de Pesquisas da Amazônia (INPA), Laboratório de Ecofisiologia e Evolução Molecular, Av. André Araújo 2936, 69067-375, Manaus, AM, Brasil \\ 2 Universidade Nilton Lins, Programa de Pós-graduação em Aquicultura, Av. Professor Nilton Lins 3259, 69058-030, Manaus, AM, Brasil \\ * Corresponding author: arlanpaz.inpa@gmail.com
}

\begin{abstract}
Colossoma macropomum, known locally as tambaqui, is the native fish most farmed in Brazil, however, technological advances are needed to reach efficient production rates. Modulating growth factors, such as growth hormone, may be associated with improved growth rate and feed efficiency. The use of exogenous hormone for fish rearing is prohibited in Brazil, yet the experimental use of bovine hormone can be useful in research aimed at understanding how to stimulate endogenous growth hormones in fish. Therefore, the present study had the strict objective of understanding the effects of growth hormone on the physiology and zootechnical parameters of $C$. macropomum under experimental conditions. The animals were intraperitoneally injected every fifteen days with 1,10 and $100 \mu \mathrm{g} \mathrm{g}^{-1}$ of bGH using $0.9 \% \mathrm{NaCl}$ saline as diluent. The 10 and $100 \mu \mathrm{g} \mathrm{g}^{-1}$ bolus had a positive effect on the performance indexes of C. macropomum: weight gain $(\mathrm{g})$, growing length $(\mathrm{cm})$, daily weight gain (g), feed conversion and specific growth rate (\% per day). The bGH promoted a greater increase in length than in mass, which caused a reduction in condition factor of the individuals receiving a bolus of 10 and $100 \mu \mathrm{g} \mathrm{g}^{-1}$. Furthermore, bGH caused no changes in glucose levels, cortisol, hematological parameters, plasma levels of $\mathrm{Na}^{+}$and $\mathrm{K}^{+}$, and activity of gill's $\mathrm{H}^{+}$-ATPase and $\mathrm{Na}^{+}, \mathrm{K}^{+}$-ATPase, at least during the experimental period considered in the present study.
\end{abstract}

KEYWORDS: aquaculture, growth performance, osmorregulation, hematological parameters

\section{Manipulação do crescimento do peixe amazônico tambaqui, Colossoma macropomum (Characiformes: Serrasalmidae): análises}

\section{fisiológicas e zootécnicas}

\section{RESUMO}

O tambaqui, Colossoma macropomum, é o peixe nativo mais cultivado no Brasil. No entanto, avanços tecnológicos são necessários para incrementar as taxas de produçáo. Fatores de crescimento moduladores, como o hormônio do crescimento, podem estar associados a uma melhoria na taxa de crescimento e eficiência alimentar. $\mathrm{O}$ uso de hormônio exógeno para a criação de peixes é proibido por lei no Brasil, porém, o uso experimental do hormônio bovino pode ser útil em pesquisas que visam determinar mecanismos de estímulo dos hormônios de crescimento endógenos em peixes. Portanto, o presente estudo teve como objetivo estrito a compreensão dos efeitos do hormônio de crescimento sobre a fisiologia e os parâmetros zootécnicos de C. macropomum em condiçôes experimentais. Os animais foram injetados intraperitonealmente a cada quinze dias com 1, 10 e $100 \mu \mathrm{g} \mathrm{g}^{-1} \mathrm{de}^{-1}$ bGH, utilizando solução salina a $0,9 \% \mathrm{de} \mathrm{NaCl}$ como diluente. Observou-se que as concentraçóes 10 e $100 \mu \mathrm{g} \mathrm{g}^{-1}$ tiveram um efeito positivo sobre os índices de desempenho de C. macropomum em ganho de massa $(\mathrm{g})$, crescimento em comprimento $(\mathrm{cm})$, ganho de massa diário (g), conversão alimentar e taxa de crescimento específico (\% por dia). O bGH promoveu ganho maior em comprimento do que em massa, o que causou diminuição do fator de condição nos indivíduos que receberam 10 e 100 $\mu \mathrm{g} \mathrm{g}^{-1}$. Além disso, o bGH não causou alteraçôes nos níveis de glicose, cortisol, parâmetros hematológicos, níveis plasmáticos de $\mathrm{Na}^{+}$e $\mathrm{K}^{+}$e na atividade de $\mathrm{H}^{+}$-ATPase e $\mathrm{Na}^{+}$, $\mathrm{K}^{+}$-ATPase nas brânquias durante o período experimental.

PALAVRAS-CHAVE: aquicultura, performance em crescimento, osmorregulação, parâmetros hematológicos 


\section{INTRODUCTION}

Fish consumption will increase as the global human population increases, with aquaculture showing great potential to produce quality food in comparison with traditional fishing activities (FAO 2016). Colossoma macropomum is the most farmed native fish in Brazil (IBGE 2016), however, technological improvements are needed to reach higher efficiency and sustainable production (Bocanegra and Flores 1985; FAO 2016). The expansion of the aquaculture industry has occurred simultaneously with the development of biotechnology. A mix of strategies has been adopted to improve fish growth and meet nutrient requirements, including diets enriched with specific protein nutrients, energy levels and stimulation of endogenous hormones, such as growth hormone (GH) (Li et al. 2003; Hallerman et al. 2007; Reindl and Sheridan 2012; Budi et al. 2015; Vikesa et al. 2017).

The use of exogenous growth hormone in animal husbandry for human consumption is prohibited by current legislation in Brazil, because of possible risks to human health (Sales et al. 2015). However, its use in scientific experimentation is a valuable approach in studies that aim to understand the physiological processes that involve the growth of farm fish, to aid in the development of technologies that improve the production cycle (Peter and Marchant 1995).

The effects of $\mathrm{GH}$ on fish include an increase in feed efficiency, appetite, immunity, changes in body composition, behavior, reproductive processes, osmoregulation and tolerance to hypoxia (Li et al. 2003; Canosa et al. 2007; Hallerman et al. 2007). GH can also stimulate lipolysis and fatty acid oxidation in adipose tissue, skeletal and heart musculature and enhance hepatic glycogenolysis, increasing the plasma concentration of glucose (Polakof et al. 2011; Polakof et al. 2012). GH also can interact with cortisol, increasing the capacity of osmotic adjustments (Sakamoto and McCormick 2006). This interaction is associated with increases in plasma metabolite levels, distribution of energy reserves, as well as changes in osmotic pressure and activity of enzymes such as $\mathrm{Na}^{+}, \mathrm{K}^{+}$-ATPase and $\mathrm{H}^{+}$ATPase, which substantially aid in the adaptation of an euryhaline fish to salt water (Liebert and Schreck 2006).

The effects of GH on osmoregulation of freshwater teleosts are almost unknown (McCormick 2001; Arjona et al. 2011), as are the effects of GH on zootechnical performance, hematology of tropical fish, such as C. macropomum. GH has been described to increase growth and metabolism of tropical fish. For example, the bovine GH increased lysozyme activity, plasma immunoglobulin, and growth in Oreochromis niloticus (Leedom et al. 2002; Liñán-Cabello et al. 2013). Possibly the effects caused by exogenous $\mathrm{GH}$ occurred due to the high degree of phylogenetic conservation of this molecule, which can present a similarity of $70 \%$ to mammalian sequence, considering various species (Peter and Marchant 1995).
According to Canosa et al. (2007) and Ma et al. (2012) families of several hormones, including $\mathrm{GH}$, prolactin (PRL), somatotropin, chorionic or placental lactogen (PL) and somatolactin (SL), have arisen from the same common ancestor. For example, the GH of Tinca tinca presents low homology for the structural alignments, the amino acids at the binding sites were similar to human GH (Panicz et al. 2012).

Thus, the aim of this study was to understand the effects of bovine growth hormone (bGH) on aspects of physiology, biochemistry and growth of juveniles of C. macropomum, including hematology, stress markers, and osmorregulation.

\section{MATERIAL AND METHODS}

\section{Experimental animals}

Juveniles of $C$. macropomum were purchased from a local fish farmer and transported to the Laboratory of Ecophysiology and Molecular Evolution (LEEM) at the Instituto Nacional de Pesquisas da Amazônia (INPA), where the animals were acclimatized in outdoors tanks supplied with flow-thru low $\mathrm{CO}_{2}$ water. The Ethics Committee on Animal Experimentation of INPA approved the experimental design and methodology under the registration number $026 / 2015$, and all procedures conformed with Brazilian animal care regulations. The animals were then transferred to their respective experimental units, where they remained for ten days under natural conditions of temperature, photoperiod, and continuous aeration. The levels of dissolved $\mathrm{O}_{2}$ ranged between 5 and $7 \mathrm{mg} \mathrm{L}^{-1}$. The fish were fed extruded commercial pellets of $2-4 \mathrm{~mm}$ (NUTRIPISCIS, Brazil) to apparent satiety twice a day, at $8 \mathrm{AM}$ and $5 \mathrm{PM}$. The elemental composition of the food (measured in a companion laboratory, Fish Nutrition Laboratory at INPA) was 33.6\% crude protein, $39.3 \%$ carbohydrates, $4 \%$ fat, $2.6 \%$ crude fiber, $8.7 \%$ of dry matter and $11.8 \%$ ash.

\section{Experimental procedure}

The experiment was conducted under laboratory conditions using 144 fish weighing $51.00 \pm 4.24 \mathrm{~g}$ and measuring 14.55 $\pm 0.24 \mathrm{~cm}$ total length (mean \pm SEM). The animals were randomly assigned to four treatments with three replicates, following a completely randomized design, totaling 12 animals per experimental unit. The bGH (Lactotropin; Elanco, Brazil) was dissolved in physiological saline $(0.9 \% \mathrm{NaCl})$ to a final nominal concentration of 1,10 , and $100 \mu \mathrm{g} \mathrm{g}^{-1}$, and was injected intraperitoneally. As control treatment animals were injected only with saline solution. The experimental concentrations were based on Leedom et al. (2002) and Li et al. (2003). Each of the 12 experimental units was composed of a polyethylene tank with a capacity of $150 \mathrm{~L}$, equipped with a biological filter, continuous aeration and a flow rate of 0.5 $\mathrm{L} \mathrm{min}^{-1}$. The experiment lasted 60 days. During this period, fish were weighed and received a bolus of bGH hormone at $0,15,30$ and 45 days. At each of these timepoints, all 
animals were transferred to water at $-14^{\circ} \mathrm{C}$ to reduce their activity and were weighed to the nearest $0.1 \mathrm{~g}$ using a digital balance, and had the total length (from the beginning of the head to the end of the caudal fin) measured to the nearest $0.1 \mathrm{~cm}$ using an icthiometer. The bolus of bGH to be injected was based on the measured weight of each animal. For this purpose, three solutions were prepared with the following concentrations: $0.2 ; 2$ and $20 \mu \mathrm{g} \mu \mathrm{L}^{-1}$. These solutions were used in animals injected with 1,10 and $100 \mu \mathrm{g} \mathrm{g}^{-1} \mathrm{bGH}$ concentration, respectively. Thus, animals of $50 \mathrm{~g}$ received a bolus of $250 \mu \mathrm{L}$, using an insulin syringe $(1 \mathrm{~mL})$. This procedure was used in order to standardize the amount of injected solution.

Nine fish per treatment, three per tank, were randomly collected for physiological analysis. The animals were euthanized by severing the spinal cord, and gill tissue was collected for the measurement of $\mathrm{Na}^{+}, \mathrm{K}^{+}$-ATPase and $\mathrm{H}^{+}$ATPase activity. Stocking density was adjusted after every biometry to maintain the living mass of $5 \mathrm{~g} \mathrm{~L}^{-1}$ of water. Physical and chemical parameters of the water were measured at the beginning and throughout the experimental period, three times a week at 9:00 am (Table 1).

\section{Growth performance}

Daily weight gain (DWG), weight gain, growth in length, feeding efficiency (FE), specific growth rate (SGR), condition factor $(\mathrm{CF})$ and total average individual food consumption (IFC) were determined as follows:

DWG $(\mathrm{g})=[$ final weight $(\mathrm{g})$ - initial weight $(\mathrm{g})] /$ time (days);

$\mathrm{FE}=$ weight gain in the period $(\mathrm{g}) /$ amount of feed provided $(\mathrm{g})$;

$$
\begin{aligned}
\text { SGR }(\% \text { day })= & {[(\ln \text { final weight }-\ln \text { initial weight })] / } \\
& \text { number of days }{ }^{*} 100 ;
\end{aligned}
$$

$$
\mathrm{CF}=\text { weight } / \text { length }{ }^{3} \text {; }
$$

IFC $(\mathrm{g})=\Sigma$ [amount of feed consumed (g) the period]/total individuals.

\section{Blood parameters}

Nine fish per treatment at 15,30, 45 and 60 days timepoints were bled from the tail vessel using a $3 \mathrm{~mL}$ heparinized (lithium heparin $5.000 \mathrm{IU}$ ) syringe. The samples were then stored in $2 \mathrm{~mL}$ microtubes (Eppendorf) and were kept on ice. Whole blood was 1:200 diluted in citrate formaldehyde solution (3.8 g of sodium citrate, $2 \mathrm{~mL}$ of $40 \%$ formalin and distilled water qsp $100 \mathrm{~mL}$ ) for red blood cell counting under 400X magnification using a Neubauer chamber and an optical microscope Motic Professional B5 (Motic, USA). The hematocrit was determined by the microhematocrit method as described by Goldenfarb et al. (1971). Blood hemoglobin $\mathrm{Hb}$ concentration was measured by the cyanmethemoglobin method as described by van Kampen and Zijlstra (1961). Mean corpuscular volume (MCV), mean corpuscular hemoglobin $(\mathrm{MCH})$ and mean corpuscular hemoglobin concentration (MCHC) were calculated as described by Brown (1976). Blood samples were centrifuged at 1835 RCF in a Eppendorf 5430R centrifuge (Eppendorf, Germany) to separate the plasma for determination of plasma glucose, cortisol and $\mathrm{Na}^{+}$ and $\mathrm{K}^{+}$. Plasma glucose was determined using an In Vitro kit (In Vitro Diagnóstico Ltda, Brazil), following manufacturer instructions, and a microplate spectrophotometer Spectramax 384 PLUS (Molecular Devices, USA) as outlined by Bartoňková et al. (2016). Cortisol was determined using a commercial ELISA kit (DBC, Diagnostics Biochem Inc, Canada) according to methods previously outlined by Kelly and Wood (2001). Plasma concentrations of $\mathrm{Na}^{+}$and $\mathrm{K}^{+}$ were determined using atomic absorption spectrophotometry (AAnalyst 800, Perkin-Elmer, USA) in flame mode.

\section{$\mathrm{Na}^{+}, \mathrm{K}^{+}$-ATPase and $\mathrm{H}^{+}$-ATPase activities}

The first gill arch was excised, frozen in liquid nitrogen, and stored at $-80^{\circ} \mathrm{C}$ before the determination of $\mathrm{Na}^{+}, \mathrm{K}^{+}$-ATPase and $\mathrm{H}^{+}$-ATPase activities as described by Kültz and Somero (1995). Frozen gill tissues were homogenized (1:10) in SEID buffer $(150 \mathrm{mM}$ sucrose, $50 \mathrm{mM}$ imidazole, $10 \mathrm{mM}$ EDTA, $0.5 \%$ Na-deoxycholate, $\mathrm{pH} 7.5)$, centrifuged at 4 ${ }^{\circ} \mathrm{C}, 4758 \mathrm{RCF}$ in a Eppendorf 5430R centrifuge (Eppendorf,

\begin{tabular}{|c|c|c|c|c|}
\hline Parameter & Control & $1 \mu \mathrm{g} \mathrm{g}^{-1}$ & $10 \mu \mathrm{g} \mathrm{g}^{-1}$ & $100 \mu \mathrm{g} \mathrm{g}^{-1}$ \\
\hline $\mathrm{DO}\left(\mathrm{mg} \mathrm{L}^{-1}\right)$ & $5.64 \pm 0.32$ & $5.68 \pm 0.21$ & $5.51 \pm 0.48$ & $5.03 \pm 0.35$ \\
\hline Temp $\left({ }^{\circ} \mathrm{C}\right)$ & $27.46 \pm 1.15$ & $27.49 \pm 1.12$ & $27.38 \pm 1.10$ & $27.53 \pm 1.22$ \\
\hline $\mathrm{pH}$ & $6.25 \pm 0.50$ & $6.26 \pm 0.52$ & $6.22 \pm 0.54$ & $6.21 \pm 0.51$ \\
\hline Cond $\left(\mu \mathrm{cm}^{-1}\right)$ & $110.76 \pm 35.65$ & $107.73 \pm 35.72$ & $109.39 \pm 36.24$ & $112.57 \pm 33.89$ \\
\hline Ammonia $\left(\mu \mathrm{M} \mathrm{L}^{-1}\right)^{\mathrm{b}}$ & $39.50 \pm 14.30$ & $43.74 \pm 16.79$ & $39.86 \pm 14.97$ & $44.01 \pm 19.55$ \\
\hline $\mathrm{Na}^{+}\left(\mu \mathrm{ML}^{-1}\right)$ & $140.76 \pm 11.49$ & $138.61 \pm 17.46$ & $137.60 \pm 11.15$ & $146.76 \pm 10.44$ \\
\hline $\mathrm{K}^{+}\left(\mu \mathrm{ML}^{-1}\right)$ & $78.51 \pm 10.80$ & $77.79 \pm 14.45$ & $77.38 \pm 7.71$ & $85.37 \pm 11.62$ \\
\hline $\mathrm{Cl}^{-}\left(\mu \mathrm{ML}^{-1}\right)$ & $73.10 \pm 9.44$ & $64.16 \pm 14.34$ & $81.47 \pm 13.56$ & $76.62 \pm 15.33$ \\
\hline $\mathrm{Ca}^{2+}\left(\mu \mathrm{M} \mathrm{L}^{-1}\right)$ & $6.19 \pm 1.67$ & $5.54 \pm 2.04$ & $5.20 \pm 1.37$ & $6.38 \pm 1.70$ \\
\hline
\end{tabular}

Table 1. Physicochemical characteristics of the water in the experimental units: dissolved oxygen (DO), temperature (Temp), pH, conductivity (Cond), total ammonia and levels of sodium $\left(\mathrm{Na}^{+}\right)$, potassium $\left(\mathrm{K}^{+}\right)$, chloride $(\mathrm{Cl})$ and calcium $\left(\mathrm{Ca}^{2+}\right)$. Data presented as mean $\pm \mathrm{SEM}$.

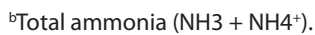


Germany) and the supernatants were saved for enzyme determinations. $5 \mu \mathrm{L}$ of the supernatant of each sample were added to 12 microplate wells, and were incubated with the reaction solution $(30 \mathrm{mM}$ imidazole, $45 \mathrm{mM} \mathrm{NaCl}, 15$ $\mathrm{mM} \mathrm{KCl}, 3 \mathrm{mM} \mathrm{MgCl} \cdot 6 \mathrm{H}_{2} \mathrm{O}, 0.4 \mathrm{mM} \mathrm{KCN}, 1.0 \mathrm{mM}$ ATP, $0.2 \mathrm{mM} \mathrm{NADH}, 0.1 \mathrm{mM}$ fructose 1.6 diphosphate, 2 $\mathrm{mM}$ phosphoenolpyruvate, $3 \mathrm{IU} \mathrm{mL}^{-1}$ pyruvate kinase and $2 \mathrm{IU} \mathrm{mL}^{-1}$ lactate dehydrogenase). Additionally, out of the 12 wells, four received additional $2 \mathrm{mM}$ ouabain and four $2 \mathrm{mM} \mathrm{N}$-ethylmaleimide. The assay is based on inhibition of $\mathrm{Na}^{+}, \mathrm{K}^{+}$-ATPase activity by ouabain and $\mathrm{H}^{+}$-ATPase by $\mathrm{N}$-ethylmaleimide. The NADH oxidation rate was read over $10 \mathrm{~min}$ at $340 \mathrm{~nm}$ at $25^{\circ} \mathrm{C}$. The activity of $\mathrm{Na}^{+}, \mathrm{K}^{+}$-ATPase and $\mathrm{H}^{+}$-ATPase was calculated as the difference between total activity to ouabain or to $\mathrm{N}$-ethylmaleimide treated samples, respectively. Protein concentrations of crude homogenates were determined using the Bradford method (Bradford 1976). The activities of $\mathrm{Na}^{+}$, $\mathrm{K}^{+}$-ATPase and $\mathrm{H}^{+}$-ATPase are expressed as micromole ATP mg protein ${ }^{-1} \mathrm{~h}^{-1}$.

\section{Statistical analyses}

The results are presented as mean \pm SEM (standard error of the mean). Fish mass $(\mathrm{g})$ and length $(\mathrm{cm})$ were analyzed and adjusted using the Cochran test $(p<0.05)$ to ensure homogeneity at the beginning of the experiment. Data normality was checked using Shapiro-Wilk test. For statistical analysis, a two-way ANOVA (time and bGH) was used, followed by a Tukey test comparison to discriminate the significant differences $(\mathrm{p}<0.05)$. One dataset without a normal distribution was analyzed using the non-parametric Kruskal-Wallis test, and the significance of the differences was compared by the Dunn's test $(p<0.001)$. A non-linear quadratic exponential regression was performed to determine the behavior of mass gain and length over the 60 experimental days.

\section{RESULTS}

A significant weight gain was observed 15 days after initial treatment for the animals injected with $100 \mu \mathrm{g} \mathrm{g}^{-1} \mathrm{bGH}$ compared to all other experimental conditions (control: $\mathrm{p}=$ 0.012; $\left.1 \mu \mathrm{g} \mathrm{g}^{-1} \mathrm{p}=0.022 ; 10 \mu \mathrm{g} \mathrm{g}^{-1} \mathrm{p}=0.043\right)$. The weight gain persisted over the entire experimental period, and at day 60 the animals injected with $100 \mu \mathrm{g} \mathrm{g}^{-1}$ had gained $43.86 \%$ in weight in relation to control animals (Figure 1A). Weight gain over the experimental period was described by the following quadratic polynomial equations (Figure 1A): Control: $\mathrm{Y}=$ $-0.0043+0.3963 x 0.0048 \mathrm{x}^{2}, \mathrm{R}^{2}=0.999 ; 1 \mu \mathrm{g} \mathrm{g} \mathrm{g}^{-1}: \mathrm{Y}=0.5735$ $+0.3638 \mathrm{x}+0.0048 \mathrm{x}^{2}, \mathrm{R}^{2}=0.998 ; 10 \mu \mathrm{g} \mathrm{g}^{-1}: \mathrm{Y}=0.6715+$ $0.306 \mathrm{x}+0.0089 \mathrm{x}^{2}, \mathrm{R}^{2}=0.998 ; 100 \mu \mathrm{g} \mathrm{g} \mathrm{g}^{-1}: \mathrm{Y}=0.7592+$ $0.0982 x+0.009 x^{2}, R^{2}=0.997$.

The growth hormone caused a dose-response increase of fish length and weight over time (Length, treatments: $\mathrm{F}=$ 27.978, $\mathrm{p}<0.001$; time: $\mathrm{F}=207.13, \mathrm{p}<0.001$; interaction $\mathrm{F}=5.22, \mathrm{p}<0.001$. Weight, treatments: $\mathrm{F}=55.99 \mathrm{p}<0.001$; time: $\mathrm{F}=376.12, \mathrm{p}<0.001$; interaction: $\mathrm{F}=4.43, \mathrm{p}<0.001)$. After 45 and 60 days, there was significantly greater growth in length (Figure 1B) of animals injected with 10 and $100 \mu \mathrm{g}$ $\mathrm{g}^{-1} \mathrm{bGH}$ relative to control animals and to animals injected with $1 \mu \mathrm{g} \mathrm{g}^{-1}$. At 60 days the animals that received 10 and $100 \mathrm{gg} \mathrm{g}^{-1} \mathrm{bGH}$ presented an increase of $66.9 \%$ and $74.3 \%$ in length, respectively, relative to the control. In contrast, animals injected with $1 \mu \mathrm{g} \mathrm{g}^{-1}$, did not present a significant growth increase compared to control (Fig. 1B). Growth performance in length over the experimental period was described by the following quadratic polynomial equations (Figure 1B): Control: $\mathrm{Y}=0.0366+0.0647 \mathrm{x}+0.0010 \mathrm{x}^{2}, \mathrm{R}^{2}=0.999 ; 1 \mu \mathrm{g}$ $\mathrm{g}^{-1}: \mathrm{Y}=0.1180+0.0326 \mathrm{x}+0.0018 \mathrm{x}^{2}, \mathrm{R}^{2}=0.997 ; 10 \mu \mathrm{g} \mathrm{g}^{-1}:$ $\mathrm{Y}=0.1474+0.0172 \mathrm{x}+0.0032 \mathrm{x}^{2}, \mathrm{R}^{2}=0.998 ; 100 \mu \mathrm{g} \mathrm{g}^{-1}: \mathrm{Y}$ $=0.2126+0.0435 \mathrm{x}+0.0029 \mathrm{x}^{2}, \mathrm{R}^{2}=0.997$.

Daily weight gain (DWG) increased significantly for animals injected with 10 and $100 \mu \mathrm{g} \mathrm{g}^{-1}$ over the experimental period $(\mathrm{p}<0.001)$ (Table 2). Feed efficiency (FE) and condition

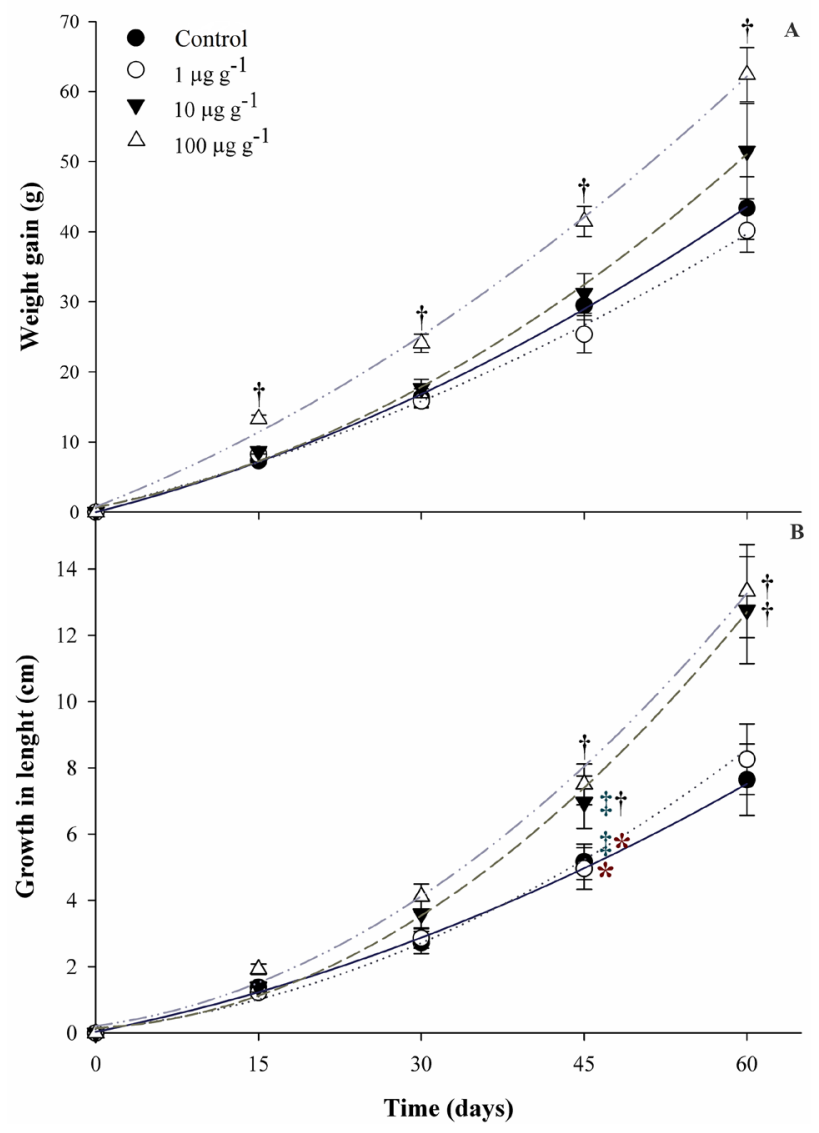

Figure 1. Effect of intraperitoneal injection of growth hormone (Lactotropin ${ }^{a}$ ) on the growth in weight (A) and length (B) of juvenile tambaqui (Colossoma macropomum) in experimental conditions. Results are expressed as mean \pm SEM $(n=3, N=3)$. Data points containing a symbol are significantly different from those that do not share the same symbol within the same sampling period $(p<0.05)$. The quadratic effect of the curves is explained by $Y=y 0+a x+b x^{2}$ where: $Y=$ length in gain and growth in length ( $\mathrm{cm}$ ); $x=$ time (days); $y 0$, and $b=$ coefficients. This figure is in color in the electronic version. 
factor (CF) were also improved $(\mathrm{p}<0.05)$ in animals injected with $100 \mu \mathrm{g} \mathrm{g}^{-1}$. Average individual food consumption (IFC) increased at day 45 in animals that received $100 \mu \mathrm{gg}^{-1}(\mathrm{p}<0.05)$.

Except for decreased hematocrit in animals injected with 10 and $100 \mu \mathrm{g} \mathrm{g}^{-1}$ at day 60, compared to control and $1 \mu \mathrm{g} \mathrm{g}^{-1}$ ( $\mathrm{p}=$ 0.045 and $\mathrm{p}=0.028$, respectively), no changes were observed for all other hematological parameters (Table 3). Cortisol levels showed no difference $(F=0.209, \mathrm{p}=0.933)$ among treatments at any sampling time, except for a decrease observed at day 15 ( $\mathrm{p}<0.001$ for all comparisons) (Figure 2A). Likewise, except for the variation observed in control animals over the whole experimental period, plasma glucose levels showed no changes among the experimental treatments (Figure 2B).

The activity of $\mathrm{Na}^{+}, \mathrm{K}^{+}$-ATPase was reduced over time in all treatments, except for control animals (Figure 3A). In contrast, no differences in the activities of $\mathrm{H}^{+}$-ATPase were observed over the whole experimental period (Figure 3B). The lowest values for plasma levels of sodium $\left(\mathrm{Na}^{+}\right)$were observed at day 45 , while no changes among treatments over time were observed for potassium levels $\left(\mathrm{K}^{+}\right)$(Figure 4).

\section{DISCUSSION}

The use of intraperitoneal injection of bovine growth hormone to improve growth of $C$. macropomum juveniles was shown to be effective, as the administration of bGH at the two highest doses $\left(10\right.$ and $\left.100 \mu \mathrm{g} \mathrm{g}^{-1}\right)$ caused an increase in weight, length, specific growth rate and daily weight gain. Similar effects have been described for other farmed fish species, such as Scaphirhynchus platorhynchus, Sparus aurata, Oncorhynchus mykiss, Oreochromis niloticus and Paralichthys olivaceus (Cavari et al. 1993; Moriyama et al. 1993; Leedom et al. 2002; Li et al. 2003; Liu et al. 2012; Fenn and Small 2015). The growth improvement is likely to be due to the direct effect of GH up regulating protein synthesis, and to the indirect effect on cell metabolism. In muscle and liver, for example, GH stimulates the release of insulin release factors (Leggatt et al. 2009). Among these factors is IGF-1 (insulin growth factor-I) which acts as a regulator of amino acid transport to the tissues, and as a signal for cell division (Hossner 2005; Takei and Loretz 2006; Reindl and Sheridan 2012).

Liñan-Cabello et al. (2013) suggested that growth may be promoted by increased amino acid transport into

Table 2. Effects of intraperitoneal application of growth hormone (Lactotropin") on daily weight gain (DWG), specific growth rate (SGR), feed efficiency (FE), average individual food consumption (IFC) and condition factor (CF) in juvenile tambaqui (Colossoma macropomum) in experimental conditions. Results are shown as mean $\pm \operatorname{SEM}(n=3, N=3)$. Different small letters indicate significant differences among treatments at a given collecting time. Different capital letters indicate differences within a given treatment over time $(p<0.05)$.

\begin{tabular}{|c|c|c|c|c|c|}
\hline $\begin{array}{l}\text { bGH concentration } \\
\left(\mu \mathrm{g} \mathrm{g}^{-1}\right)\end{array}$ & $\begin{array}{l}\text { DWG* }^{*} \\
(\mathrm{~g})\end{array}$ & $\begin{array}{c}\text { SGR } \\
\text { (\% in day) }\end{array}$ & $\begin{array}{l}\mathrm{FE} \\
(\%)\end{array}$ & $\begin{array}{l}\text { IFC } \\
\text { (g) }\end{array}$ & $\begin{array}{l}\text { CF } \\
(\%)\end{array}$ \\
\hline & & & After 15 days & & \\
\hline Control & $0.63 \pm 0.05^{a}$ & $14.63 \pm 0.68^{\AA}$ & $0.63 \pm 0.02^{2 \mathrm{~A}}$ & $12.91 \pm 0.70^{A}$ & $1.67 \pm 0.02^{2 \mathrm{~A}}$ \\
\hline 1 & $0.55 \pm 0.04^{a}$ & $13.62 \pm 0.24^{\AA}$ & $0.57 \pm 0.01^{\mathrm{a}}$ & $13.67 \pm 0.75^{A}$ & $1.66 \pm 0.02^{\mathrm{a}}$ \\
\hline 10 & $0.59 \pm 0.04^{a}$ & $14.50 \pm 0.42^{\mathrm{A}}$ & $0.68 \pm 0.05^{\mathrm{AAB}}$ & $13.17 \pm 0.94^{A}$ & $1.60 \pm 0.02^{\mathrm{ab}}$ \\
\hline \multirow[t]{2}{*}{100} & $0.94 \pm 0.05^{b}$ & $17.53 \pm 0.76^{\mathrm{A}}$ & $0.95 \pm 0.02^{\mathrm{bA}}$ & $14.92 \pm 2.00^{\AA}$ & $1.56 \pm 0.02^{\mathrm{b}}$ \\
\hline & & & After 30 days & & \\
\hline Control & $0.53 \pm 0.05^{\mathrm{a}}$ & $9.20 \pm 0.59^{B}$ & $0.35 \pm 0.06^{\mathrm{aB}}$ & $16.09 \pm 1.75^{A}$ & $1.72 \pm 0.03^{\mathrm{aA}}$ \\
\hline 1 & $0.49 \pm 0.03^{\mathrm{a}}$ & $8.94 \pm 0.41^{\mathrm{B}}$ & $0.41 \pm 0.03^{\mathrm{ab}}$ & $16.73 \pm 1.49^{A B}$ & $1.71 \pm 0.02^{\mathrm{a}}$ \\
\hline 10 & $0.55 \pm 0.04^{a}$ & $9.35 \pm 0.46^{\mathrm{B}}$ & $0.45 \pm 0.06^{\mathrm{abA}}$ & $15.91 \pm 1.41^{\mathrm{A}}$ & $1.63 \pm 0.02^{\mathrm{ab}}$ \\
\hline \multirow[t]{2}{*}{100} & $0.80 \pm 0.04^{b}$ & $10.66 \pm 0.78^{B}$ & $0.62 \pm 0.02^{\mathrm{bB}}$ & $18.31 \pm 2.19^{A B}$ & $1.58 \pm 0.02^{b}$ \\
\hline & & & After 45 days & & \\
\hline Control & $0.64 \pm 0.06^{a}$ & $7.43 \pm 0.79^{c}$ & $0.59 \pm 0.07^{\mathrm{AB}}$ & $17.68 \pm 0,56^{\mathrm{aA}}$ & $1.68 \pm 0.02^{A}$ \\
\hline 1 & $0.56 \pm 0.06^{a}$ & $7.16 \pm 0.94^{c}$ & $0.67 \pm 0.14$ & $16.59 \pm 1.15^{\mathrm{aAB}}$ & $1.66 \pm 0.02$ \\
\hline 10 & $0.69 \pm 0.06^{\mathrm{ab}}$ & $7.63 \pm 0.59^{c}$ & $0.78 \pm 0.06^{B}$ & $17.85 \pm 0.50^{\mathrm{aA}}$ & $1.61 \pm 0.02$ \\
\hline \multirow[t]{2}{*}{100} & $0.92 \pm 0.05^{b}$ & $8.26 \pm 0.55^{\mathrm{CD}}$ & $0.78 \pm 0.11^{\mathrm{AB}}$ & $22.21 \pm 1.49^{\mathrm{bAB}}$ & $1.61 \pm 0.03$ \\
\hline & & & After 60 days & & \\
\hline Control & $0.76 \pm 0,11^{\mathrm{ab}}$ & $6.73 \pm 0.66^{D}$ & $0.63 \pm 0.05^{A}$ & $27.05 \pm 3.15^{B}$ & $1.86 \pm 007^{\mathrm{aB}}$ \\
\hline 1 & $0.66 \pm 0.08^{a}$ & $6.30 \pm 0.69^{D}$ & $0.62 \pm 0.04$ & $21.27 \pm 1.75^{B}$ & $1.75 \pm 0.02^{\mathrm{ab}}$ \\
\hline 10 & $1.01 \pm 0.13^{b}$ & $6.64 \pm 0.59^{D}$ & $0.65 \pm 0.12^{\mathrm{AB}}$ & $27.87 \pm 5.93^{B}$ & $1.68 \pm 0.02^{b}$ \\
\hline 100 & $1.09 \pm 0.06^{b}$ & $6.88 \pm 0.41^{\mathrm{D}}$ & $0.82 \pm 0.04^{\mathrm{AB}}$ & $30.54 \pm 5.51^{B}$ & $1.68 \pm 0.03^{b}$ \\
\hline
\end{tabular}

*DWG data were analyzed by Kruskal-Wallis test, and the differences were compared using Dunn's test $(p<0.001)$. SGR, FE, TIR and CF were analyzed by ANOVA, followed by Tukey post hoc test $(p<0.05)$ 
Table 3. Effects of intraperitoneal application of growth hormone (Lactotropin ${ }^{\circ}$ ) on hematocrit ( $\left.\mathrm{Ht}\right)$, blood hemoglobin (Hb), red blood cells (RBC), mean corpuscular volume (MCV), mean corpuscular hemoglobin (MCH) and mean corpuscular hemoglobin concentration (MCHC) in juvenile tambaqui (Colossoma macropomum) in experimental conditions. Results are shown as mean $\pm \operatorname{SEM}(n=3, N=3)$. Different letters indicate significant diff-erences among treatments at a given time point $(p<0.05)$.

\begin{tabular}{|c|c|c|c|c|c|c|}
\hline $\begin{array}{l}\text { Concentration } \\
\left(\mu \mathrm{g} \mathrm{g}^{-1}\right)\end{array}$ & $\begin{array}{l}\mathrm{Ht} \\
(\%)\end{array}$ & $\begin{array}{c}\mathrm{Hb} \\
\left(\mathrm{g} \mathrm{dL}^{-1}\right)\end{array}$ & $\begin{array}{c}\mathrm{RBC} \\
\left(\text { neerit. }^{10} 6 / \mathrm{mm}^{3}\right) \\
\end{array}$ & $\begin{array}{l}\mathrm{MCV} \\
\left(\mu \mathrm{m}^{3}\right)\end{array}$ & $\begin{array}{l}\mathrm{MCH} \\
(\mathrm{pg}) \\
\end{array}$ & $\begin{array}{c}\mathrm{MCHC} \\
(\%)\end{array}$ \\
\hline & \multicolumn{6}{|c|}{ After 15 days } \\
\hline Control & $30.06 \pm 0.96$ & $7.88 \pm 0.27$ & $1.64 \pm 0.07$ & $184.76 \pm 7.22$ & $48.69 \pm 2.79$ & $26.31 \pm 0.76$ \\
\hline 1 & $29.97 \pm 1.15$ & $8.04 \pm 0.33$ & $1.67 \pm 0.06$ & $179.71 \pm 4.96$ & $48.38 \pm 2.22$ & $26.89 \pm 0.81$ \\
\hline 10 & $29.94 \pm 0.70$ & $8.23 \pm 0.20$ & $1.85 \pm 0.06$ & $162.78 \pm 4.42$ & $44.69 \pm 0.82$ & $27.53 \pm 0.52$ \\
\hline \multirow[t]{2}{*}{100} & $26.00 \pm 0.95$ & $7.52 \pm 0.23$ & $1.56 \pm 0.06$ & $168.70 \pm 9.13$ & $48.64 \pm 2.04$ & $28.97 \pm 0.42$ \\
\hline & \multicolumn{6}{|c|}{ After 30 days } \\
\hline Control & $27.88 \pm 1.10$ & $7.96 \pm 0.31$ & $1.85 \pm 0.14$ & $156.76 \pm 10.52$ & $43.99 \pm 1.55$ & $28.91 \pm 1.69$ \\
\hline 1 & $29.16 \pm 1.42$ & $8.12 \pm 0.29$ & $1.83 \pm 0.10$ & $161.78 \pm 8.55$ & $45.05 \pm 1.93$ & $28.02 \pm 0.58$ \\
\hline 10 & $29.27 \pm 0.99$ & $8.41 \pm 0.37$ & $1.85 \pm 0.07$ & $159.02 \pm 3.97$ & $45.93 \pm 2.48$ & $28.77 \pm 0.98$ \\
\hline \multirow[t]{2}{*}{100} & $26.50 \pm 0.93$ & $7.12 \pm 0.31$ & $1.72 \pm 0.08$ & $154.45 \pm 5.19$ & $41.50 \pm 1.57$ & $26.88 \pm 0.60$ \\
\hline & \multicolumn{6}{|c|}{ After 45 days } \\
\hline Control & $29.11 \pm 0.6$ & $7.47 \pm 0.21$ & $1.49 \pm 0.07$ & $197.86 \pm 8.01$ & $50.64 \pm 1.78$ & $25.68 \pm 0.61$ \\
\hline 1 & $28.61 \pm 1.40$ & $7.43 \pm 0.45$ & $1.59 \pm 0.09$ & $181.92 \pm 6.97$ & $46.98 \pm 1.54$ & $25.97 \pm 0.88$ \\
\hline 10 & $28.44 \pm 0.84$ & $7.72 \pm 0.31$ & $1.58 \pm 0.10$ & $183.20 \pm 8.27$ & $49.48 \pm 1.80$ & $27.17 \pm 0.78$ \\
\hline \multirow[t]{2}{*}{100} & $27.37 \pm 1.68$ & $7.29 \pm 0.54$ & $1.47 \pm 0.11$ & $188.59 \pm 8.86$ & $49.71 \pm 1.90$ & $26.61 \pm 1.15$ \\
\hline & \multicolumn{6}{|c|}{ After 60 days } \\
\hline Control & $33.55 \pm 1.00^{\mathrm{b}}$ & $9.03 \pm 0.33$ & $1.82 \pm 0.13$ & $193.35 \pm 16.65$ & $51.17 \pm 3.11$ & $27.10 \pm 1.32$ \\
\hline 1 & $31 \pm 0.68^{\mathrm{ab}}$ & $8.77 \pm 0.24$ & $1.81 \pm 0.10$ & $174.19 \pm 8.01$ & $49.46 \pm 2.72$ & $28.37 \pm 0.87$ \\
\hline 10 & $29.44 \pm 1.14^{a}$ & $8.85 \pm 0.63$ & $1.64 \pm 0.06$ & $180.58 \pm 7.41$ & $54.28 \pm 3.95$ & $29.97 \pm 1.58$ \\
\hline 100 & $29.16 \pm 0.70^{\mathrm{a}}$ & $8.99 \pm 0.39$ & $1.85 \pm 0.11$ & $162.04 \pm 10.94$ & $49.52 \pm 2.89$ & $30.84 \pm 1.05$ \\
\hline
\end{tabular}

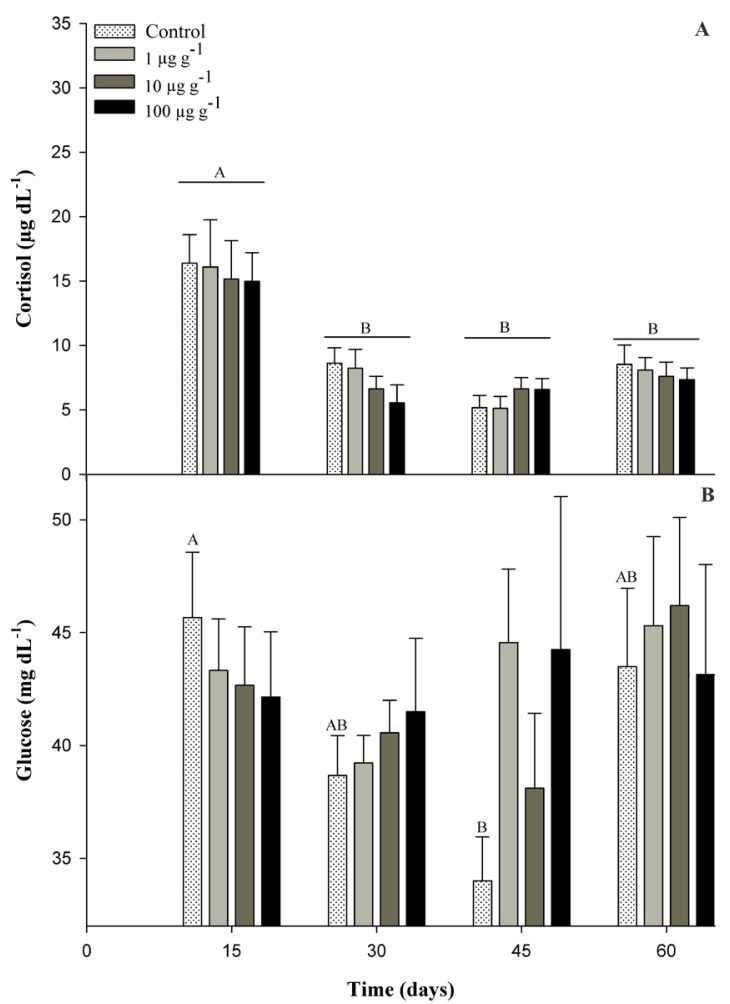

Figure 2. Effect of intraperitoneal injection of growth hormone (Lactotropin $\left.{ }^{\circ}\right)$ on plasma concentrations of cortisol (A) and glucose (B) in juvenile tambaqui (Colossoma macropomum) in experimental conditions. Results are expressed as mean $\pm \operatorname{SEM}(n=3, N=3)$. Different letters indicate significant difference for a treatment throughout the sampling period $(p<0.05)$. This figure is in color in the electronic version.

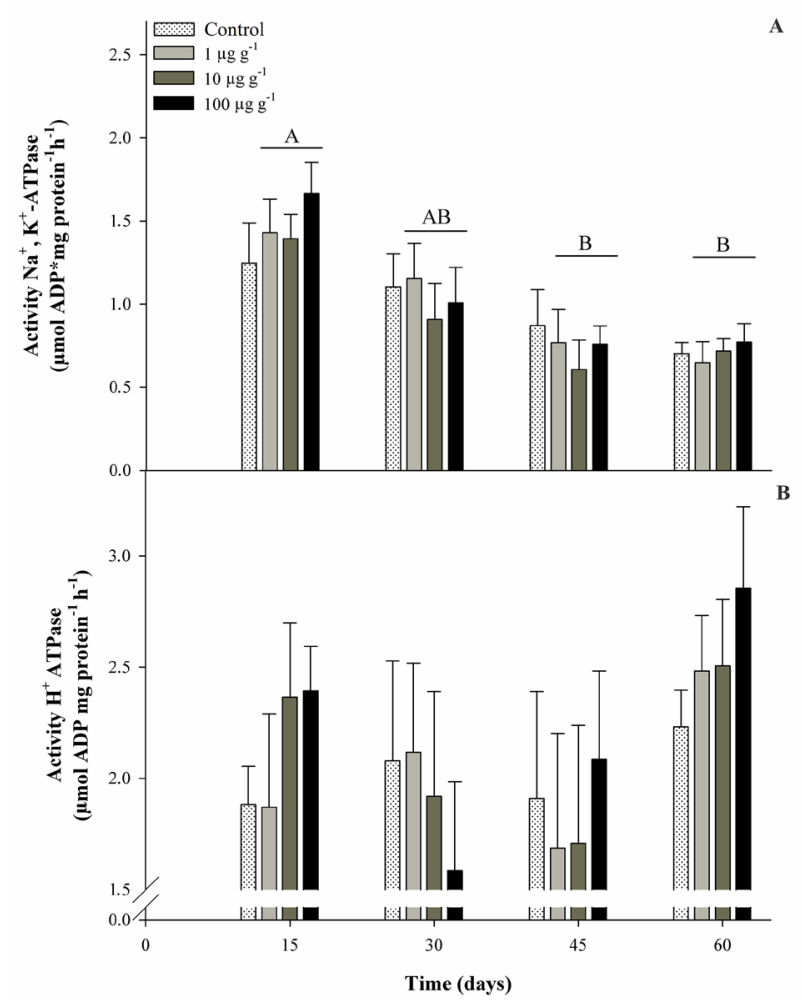

Figure 3. Effect of intraperitoneal injection of growth hormone (Lactotropin ${ }^{\circ}$ ) on activity of $\mathrm{Na}^{+}, \mathrm{K}^{+}$-ATPase (A) and $\mathrm{H}^{+}$-ATPase (B) in juvenile tambaqui (Colossoma macropomum) in experimental conditions. Results are expressed as mean \pm SEM $(n=3, N=3)$. Different letters indicate significant difference for a given treatment thoughout the sampling period $(p<0.05)$. This figure is in color in the electronic version. 


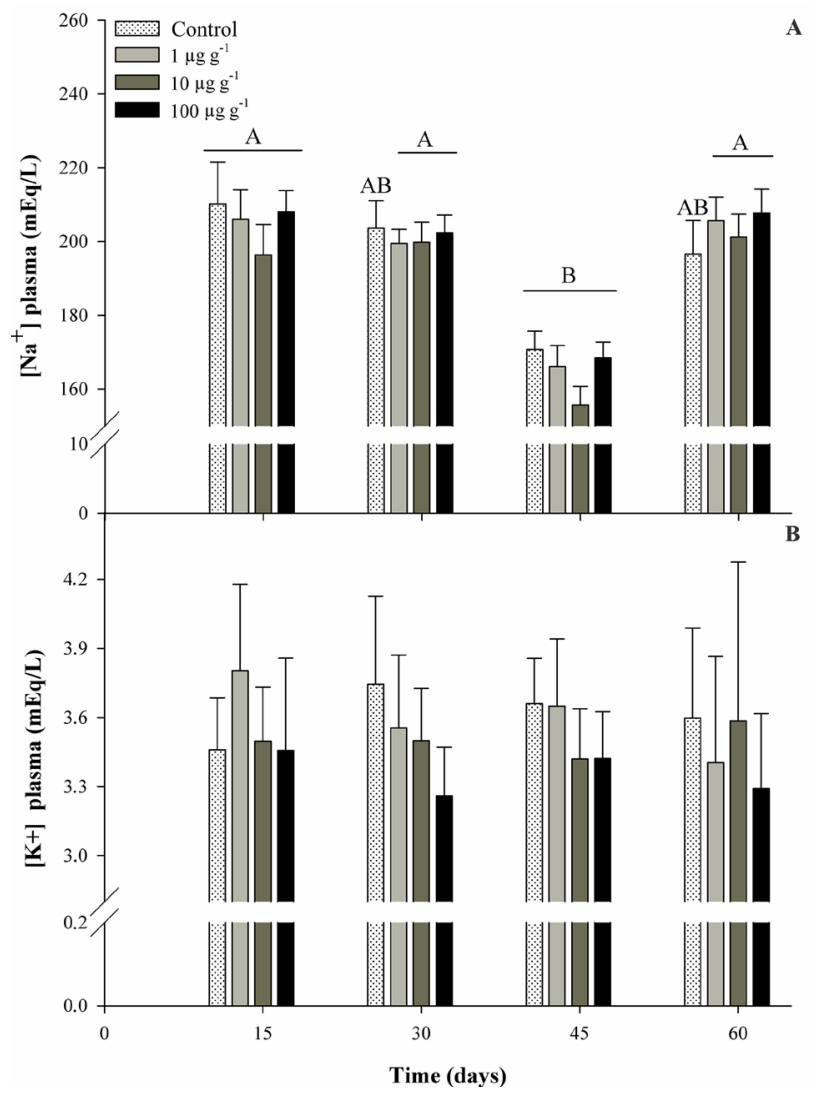

Figure 4. Effect of intraperitoneal injection of growth hormone (Lactotropin") on plasma concentrations of $\mathrm{Na}^{+}(\mathrm{A})$ and $\mathrm{K}^{+}(\mathrm{B})$ in juvenile tambaqui (Colossoma macropomum) in experimental conditions. Results are expressed as mean \pm SEM $(n=3, N=3)$. Different letters indicate significant difference for a given treatment throughout the sampling period $(p<0.05)$. This figure is in color in the electronic version.

the cell membrane and by inducing the release of fatty acids from adipose tissue, increasing the concentration of free fatty acids in body fluids. With an increased flow of fatty acids, the tissues are stimulated to convert them into acetyl-CoA, which is subsequently used as a source of energy, saving protein for growth (Bjornsson et al. 2002; Hossner 2005). However, there were no differences in blood glucose among treatments_in this study, and control animals had greater variation range of glucose over time than treatment animals. In this sense, Sangiao-Alvarellos et al. (2005) showed that injection of 2 and $5 \mu \mathrm{g} \mathrm{g}^{-1}$ of sheep growth hormone increased glycogenolys potential in the gills, kidneys, and brain of Oncorhynchus mykiss. Leung et al. (1991) also found that 50 and $100 \mu \mathrm{g} \mathrm{g}^{-1} \mathrm{bGH}$ injected in Oreochromis mossambicus caused a substantial reduction in liver glycogen and a decrease in the activity of glycogen synthase, resulting in higher plasma levels of glucose with simultaneously increased levels of amino acids. Thus, having more energy available, the larger part of the food intake could be directed to somatic growth (Bjornsson $e t$ al. 2002). Therefore, the higher growth in length of $C$. macropomum after 45 days receiving 10 and $100 \mu \mathrm{g} \mathrm{g}^{-1}$ bGH, but only for animals receiving $100 \mu \mathrm{g} \mathrm{g}^{-1}$ for growth in mass, may be the result of greater bone growth relative to muscle growth, and lipolysis in adipose tissue. Likewise, Oreochromis aureus injected with bGH for seven weeks presented higher lengths, probably because exogenous GH has little influence on the production of endogenous GH, which maximizes the influence of $\mathrm{GH}$ on growth of bone cartilage, thus impacting skeletal form (Wille et al. 2002).

The condition factor of animals reflected the increase in length of $C$. macropomum. Administration of bGH also promoted a decrease in the condition factor of Ictalurus punctatus (Peterson et al. 2004), of juveniles of Saxatilis morone (Hunt et al. 2000) and Oreochromis niloticus (LiñánCabello et al. 2013). The reasons for the stimulation of growth in length rather than in mass by bGH are unclear, and more studies are needed to explain this phenomenon. It may, however, be related to the allometric relations in tissue growth, since bone tissue has a natural priority over muscle tissue during the growth phase among vertebrates (Hossner 2005). Yet, growth in mass was also reported for fish_receiving GH. Anguilla japonica injected with a bolus of GH showed an increased incorporation of food leucine $\left[{ }^{14} \mathrm{C}\right]$ in muscle and liver, reflecting increased food intake and greater growth in mass (Inui and Ishioka 1985). Furthermore, the use of GH increased protein retention and reduced the level of lipids in fish (Macari et al. 1994; Fenn and Small 2015). Improved feed conversion and higher growth was also reported for animals receiving recombinant bovine growth hormone (Silverstein et al. 2000; Liñán-Cabello et al. 2013).

It should be also considered that anabolic hormones like GH, prolactin and IGFs affect the immune system, where the axis GH/IGF-1 plays a key role (Hooghe et al. 1993). By controlling the size of bones and organs of the animal, the GH, and IGF-1 also control, though indirectly, the hematopoietic centers in the bone marrow, increasing the production of blood cells (Clark 1997). Thus, erythropoiesis can be related to the GH affinity to prolactin and erythropoietin (Epo) (Moritz et al. 1997). Salmon (Oncorhynchus kisutch) receiving growth gene OnMTGH1 had a significant increase in hematocrit (\%), blood hemoglobin $\left(\mathrm{g} \mathrm{dL}^{-1}\right), \mathrm{MCH}, \mathrm{MCV}$ and $\mathrm{MCHC}$, and significantly decreased the number of white cells (Kim et al. 2013). In our study, however, only at day 60 did hematocrit decrease in animals injected with bGH, suggesting that bGH did not promote changes in the hematological condition of the animals. Similarly, Li et al. (2011) found no changes in hematocrit, hemoglobin, and MCHC of carp (Cyprinus carpio L.) microinjected with recombinant $\mathrm{GH}$ (pCAgcGH, transgenic gene) and subjected to exercise to exhaustion. 
The growth hormone also seems to play an important role in osmoregulation and smoltification of fish that travel between different environments (Reinecke 2010). GH acts on the acclimatization process to salt water, while prolactin acts on the acclimatization to freshwater, and cortisol interacts with both hormones facilitating the process (McCormick 2001; Sakamoto and McCormick 2006). More studies are needed to clarify the effects of GH on osmoregulation of tropical freshwater teleosts, particularly for those living in ion-poor waters, as is the case of C. macropomum.

Several studies have described increased activity of $\mathrm{Na}^{+}$, $\mathrm{K}^{+}$-ATPase in chloride cells and increased plasma osmolality in GH injected animals (Madsen et al. 1994; Arnesen et al. 2003; Handeland et al. 2003; Sangiao-Alvarellos et al. 2005). However, we observed no changes in cortisol, and in the activity of $\mathrm{Na}^{+}, \mathrm{K}^{+}$-ATPase and $\mathrm{H}^{+}$-ATPase, nor in plasma concentration of sodium and potassium in C. macropomum injected with bGH. As the analyzed animals were not subjected to an osmoregulatory challenge, there was no need for further regulation of $\mathrm{Na}^{+}, \mathrm{K}^{+}$-ATPase activity. The studies describing GH effects on $\mathrm{Na}^{+}, \mathrm{K}^{+}$-ATPase activity were carried out on animals subjected to sudden changes in water salinity (Mancera and McCormick 1998; Arnesen et al. 2003; Liebert and Schreck 2006. More research is needed to shed light on the regulation mechanisms of $\mathrm{Na}^{+}, \mathrm{K}^{+}$-ATPase activity in tropical freshwater fish.

\section{CONCLUSIONS}

In a 60-day experimental study, the growth of juvenile C. macropomum was positively influenced by bGH without detectable effects on health and osmoregulation. It is concluded that bGH may be a valuable tool in scientific studies directed towards growth manipulation. As administration to C. macropomum caused an increase in yield, further studies should focus on viable strategies that stimulate the endogenous release of GH in fish. Yet again we stress that the use of exogenous growth hormone in animal production is prohibited in Brazil, and that this study does not recommend the use of bGH in commercial $C$. macropomum aquaculture

\section{ACKNOWLEDGMENTS}

This study was supported by INCT ADAPTA (FAPEAM/ $\mathrm{CNPq}$ /CAPES). The authors acknowledge the support of Secretaria de produção rural do Amazonas - SEPROR/AM for fish supply and Maria de Nazaré Paula da Silva, Dulcilene Martins, Carolina Abrahim, Renan Amanajás, Rúbia Maielli, Grazyelle Sebrensky and Ivã Guidini for the help in carrying out the experiment. ALP and ALV were recipients, respectively, of a MSc fellowship from CAPES (Coordenação de Aperfeiçoamento de Pessoal de Nível Superior) and a research fellowship from CNPq (Conselho Nacional de Desenvolvimento Científico e Tecnológico).

\section{REFERENCES}

Arjona, F.J.; Vargas-Chacoff, L.; Martín Del Río, M.P. 2011. Effects of cortisol and thyroid hormone on peripheral outer ring deiodination and osmoregulatory parameters in the Senegalese sole (Solea senegalensis). Journal of Endocrinology, 208: 323-330.

Arnesen, A.M.; Toften, H.; Agustsson, T. 2003. Osmoregulation, feed intake, growth and growth hormone levels in 0+ Atlantic salmon (Salmo salar L.) transferred to seawater at different stages of smolt development. Aquaculture, 222: 167-187.

Bartoňková, J.; Hyršl, P.; Vojtek, L. 2016. Glucose determination in fish plasma by two different moderate methods. Acta Veterinaria Brno, 85: 349-353.

Bjornsson, B.T.; Johansson, V.; Benedet, S. 2002. Growth hormone endocrinology of salmonids: Regulatory mechanisms and mode of action. Fish Physiology and Biochemistry, 27: 227-242.

Bocanegra, A.; Flores, G. 1985. Avances en la producción de alevinos de gamitana, Colossoma macropomum y paco, C. brachypomum por reproducción inducida. Folia Amazonica, 1: 1-12.

Bradford, M.M. 1976. A rapid and sensitive method for the quantitation of microgram quantities of protein utilizing the principle of protein-dye binding. Analytical Biochemistry, 72: 248-254.

Brasil. 2016. Instituto Brasileiro de Geografia e Estatística. Produção da Pecuária Municipal. v. 44. IBGE, Rio de Janeiro, Brasil, 51p.

Brown, B.A. 1976. Hematology: Principles and Procedures. 2nd ed. Lea \& Febiger, Philadelphia, 452p

Budi, D.S.; Alimuddin; Suprauydi, M.A. 2015. Growth Response and Feed Utilization of Giant Gourami (Osphronemus goramy) Juvenile Feeding Different Protein Levels of the Diets Supplemented with Recombinant Growth Hormone. Journal of Biochemistry, 1: 12-19.

Canosa, L.F.; Chang, J.P.; Peter, R.E. 2007. Neuroendocrine control of growth hormone in fish. General and Comparative Endocrinology, 151: 1-26.

Cavari, B.; Funkenstein, B.; Chenb, T.T. 1993. Effect of growth hormone on the growth rate of the gilthead seabream (Sparus aurata), and use of different constructs for the production of transgenic fish. Biotechnology, 111: 189-197.

Clark, R. 1997. The somatogenic hormones and insulin-like growth factor-1: Stimulators of lymphopoiesis and immune function. Endocrinology Review, 18: 157-179.

FAO. 2016. Planning for aquaculture diversifications: the importance of climate change and others drives. In: Wurmann, C. G; Routledge, E. A. B. Aquaculture Diversification in South America: General views and facts and case studies of the Republic of Chile and the Federative Republic of Brasil. FAO, Rome, nr. 47, p.51 -91

FAO. 2016. The state of world fisheries and aquaculture. Contributing to food security and nutrition for all. FAO, Rome, 200p.

Fenn, C.M.; Small, B.C. 2015. Exogenous recombinant bovine growth hormone stimulates growth and hepatic IGF expression in shovelnose sturgeon Scaphirhynchus platorhynchus. Comparative Biochemistry and Physiology-Part A: Molecular and Integrative Physiology, 180: 18-22.

Goldenfarb, P.B.; Bowyer, F.P.; Hall, E.; Brosious, E. 1971. Reproducibility in the hematology laboratory: the 
microhematocrit determination. American Journal of Clinical Pathology, 56: 35-39.

Hallerman, E.M.; McLean, E.; Fleming, I.A. 2007. Effects of growth hormone transgenes on the behavior and welfare of aquacultured fishes: A review identifying research needs. Applied Animal Behaviour Science, 104: 265-294.

Handeland, S.O.; Porter, M.; Björnsson, B.T.; Stefansson, S.O. 2003. Osmoregulation and growth in a wild and a selected strain of Atlantic salmon smolts on two photoperiod regimes. Aquaculture, 222: 29-43.

Hooghe, R.; Delhase, M.; Vergani, P. 1993. Growth hormone and prolactin are paracrine growth and differentiation factors in the haemopoietic system. Immunology Today, 14: 212-214.

Hossner, K. L. 2005. Hormonal Regulation of Farm Animal Growth. CAB Publishing, Colorado. 217p.

Hunt, A.S.; Soares, J.H.; Byatt, J.C.; Dahl, G.E. 2000. The effects of exogenous bovine growth hormone and placental lactogen on juvenile striped bass, Morone saxatilis feed and growth efficiency. Journal of the World Aquaculture Society, 31: 14-21.

Inui, Y.; Ishioka, H. 1985. In vivo and in vitro effects of growth hormone on the incorporation of [14C] leucine into protein of liver and muscle of the eel. General and Comparative Endocrinology, 59: 295-300.

Kelly, S.P.; Wood, C.M. 2001. The Physiological Effects of 3, 5',3'-Triiodo-L-thyronine Alone or Combined with Cortisol on Cultured Pavement Cell Epithelia from Freshwater Rainbow Trout Gills. General and Comparative Endocrinology, 123: 280-294.

Kim, J.H.; Balfry, S.; Devlin, R.H. 2013. Disease resistance and health parameters of growth-hormone transgenic and wildtype coho salmon, Oncorhynchus kisutch. Fish and Shellfish Immunology, 34: 1553-1559.

Kültz, D.; Somero, G. 1995. Osmotic and thermal effects on in situ ATPase activity in permeabilized gill epithelial cells of the fish Gillichthys mirabilis. Journal of Experimental Biology, 198: 1883-1894.

Leedom, T.A.; Uchida, K.; Yada, T. 2002. Recombinant bovine growth hormone treatment of tilapia: growth response, metabolic clearance, receptor binding and immunoglobulin production. Aquaculture, 207: 359-380.

Leggatt, R.A.; Raven, P.A.; Mommsen, T.P. 2009. Growth hormone transgenesis influences carbohydrate, lipid and protein metabolism capacity for energy production in coho salmon (Oncorhynchus kisutch). Comparative Biochemistry and Physiology -Part B: Biochemistry and Molecular Biology, 154: 121-133.

Leung, T.C.; Ng, T.B.; Woos, N.Y.S. 1991. Metabolic in the Effects of Bovine Growth Hormone Oreochromis Mossambicus. Comparative Biochemistry and Physiology, 99: 633-636.

Li, D.; Fu, C.; Wang, Y. 2011. The hematological response to exhaustive exercise in "all-fish" growth hormone transgenic common carp (Cyprinus carpio L.). Aquaculture, 311: 263-268.

Li, Y.; Bai, J.; Jian, Q. 2003. Expression of common carp growth hormone in the yeast Pichia pastoris and growth stimulation of juvenile tilapia (Oreochromis niloticus). Aquaculture, 216: $329-341$.
Liebert, A.M.; Schreck, C.B. 2006. Effects of acute stress on osmoregulation, feed intake, IGF-1, and cortisol in yearling steelhead trout (Oncorhynchus mykiss) during seawater adaptation. General Comparative Endocrinology, 148: 195-202.

Liñán-Cabello, M.; Robles-Basto, C.; Mena-Herrera, A. 2013. Somatic growth effects of intramuscular injection of growth hormone in androgen-treated juvenile Nile tilapia, Oreochromis niloticus (Perciformes: Cichlidae). Revista de Biologia Tropical, 1: 203-212.

Liu, B.; Zang, X.N.; Liu, X.F. 2012. Stable cell-surface expression of Japanese flounder growth hormone in yeast Saccharomyces cerevisiae and growth-promoting effect on juvenile fish by oral administration. Fish Science, 78: 99-107.

Ma, Q.; ShuFang, L.; ZhiMeng, Z.; Lin, L.; ZhongZhi, S.; ChangLin, L.; Hui, M.; YongQuan, S.; QiSheng, T. 2012. Genomic structure, polymorphism and expression analysis of the growth hormone $(\mathrm{GH})$ gene in female and male Half-smooth tongue sole (Cynoglossus semilaevis). Gene, 493: 92-104.

Macari, M.; Carneiro, D.J.; Larson, M.L.; Machado, C.R. 1994. Influence of dietary protein intake and recombinant human somatotropin administration on growth and body composition of juvenile tambacu (a Piaractus mesopotamicus $\times$ Colossoma macropomum_cross). Aquaculture, 127: 363-369.

Madsen, S.S.; McCormick, S.D.; Young, G. 1994. Physiology of seawater acclimation in the striped bass, Morone saxatilis (Walbaum). Fish Physiology and Biochemistry, 13: 1-11.

Mancera, J.M.; McCormick, S.D. 1998. Osmoregulatory actions of the GH/IGF axis in non-salmonid teleosts. Comparative Biochemistry and Physiology -Part B: Biochemistry and Molecular Biology, 121: 43-48.

McCormick, S.D. 2001. Endocrine Control of Osmoregulation in Teleost Fish. American Zoologist, 41: 781-794.

Moritz, K.M.; Lim, G.B.; Wintour, E.M. 1997. Developmental regulation of erythropoietin and erythropoiesis. American Journal of Physiology, 273: 1829-1844.

Moriyama, S., Yamamotob, H.; Sugimotob, S.; Abeb, T. 1993. Oral administration of recombinant salmon growth hormone to rainbow trout, Oncorhynchus mykiss. Aquaculture, 112: 99-106.

Panicz, R.; Sadowski, J.; Drozd, R. 2012. Genetic and structural characterization of the growth hormone gene and protein from tench, Tinca tinca. Fish Physiology and Biochemistry, 38: 1645-1653.

Peter, R.E.; Marchant, T.A. 1995. The endocrinology of growth in carp and related species. Aquaculture, 129: 299-321.

Peterson, B.C.; Small, B.C.; Bosworth, B.G. 2004. Effects of bovine growth hormone (Posilac) on growth performance, body composition, and IGFBPs in two strains of channel catfish. Aquaculture, 232: 651-663.

Polakof, S.; Mommsen, T.P.; Soengas, J.L. 2011. Glucosensing and glucose homeostasis: From fish to mammals. Comparative Biochemistry and Physiology - Part B: Biochemistry and Molecular Biology, 160: 123-149.

Polakof, S.; Panserat, S.; Soengas, J.L.; Moon, T.W. 2012. Glucose metabolism in fish: A review. Journal of Comparative Physiology -Part B: Biochemical, Systems and Environmental Physiology, 182: 1015-1045. 
Reindl, K.M.; Sheridan, M.A. 2012. Peripheral regulation of the growth hormone-insulin-like growth factor system in fish and other vertebrates. Comparative Biochemistry and Physiology-Part A: Molecular and Integrative Physiology, 163: 231-245.

Reinecke, M. 2010. Influences of the environment on the endocrine and paracrine fish growth hormone-insulin-like growth factor-I system. Journal of Fish Biology, 76: 1233-1254.

Sakamoto, T.; McCormick, S.D. 2006. Prolactin and growth hormone in fish osmoregulation. General and Comparative Endocrinology, 147: 24-30.

Sales, R. L.; Rocha, J. L. M.; Bressan, J. 2015. Use of hormones and antibiotics in animal food products: general and toxicological aspects. Nutrire, 3: 409-420.

Sangiao-Alvarellos, S.; Míguez, J.M.; Soengas, J.L. 2005. Actions of growth hormone on carbohydrate metabolism and osmoregulation of rainbow trout (Oncorhynchus mykiss). General and Comparative Endocrinology, 141: 214-225.

Silverstein, J.T.; Wolters, W.R.; Shimizu, M.; Dickhoff, W.W. 2000. Bovine growth hormone treatment of channel catfish: Strain and temperature effects on growth, plasma IGF-I levels, feed intake and efficiency and body composition. Aquaculture, 190: 77-88.

Takei, Y.; Loretz, C. A. 2006. Endocrinology. In: Evans, D.H.; Claiborne, J.B. (Ed.). The Physiology of Fishes. CRC, New York. p.271-318.

van Kampen, E.J.; Zijlstra, W.G. 1961. Standardization of hemoglobinometry II. The hemiglobincyanide method. Clinica Chimica Acta, 6: 538-544.

Vikesa, V.; Nankervis, L.; Hevrøy, E.M. 2017. High dietary level stimulates growth hormone receptor and feed utilization in large Atlantic salmon (Salmo salar L.) under hypoxic conditions. Aquaculture Nutrition, 1-11.

Wille, K.; McLean, E.; Goddard, J.S.; Byatt, J.C. 2002. Dietary lipid level and growth hormone alter growth and body conformation of blue tilapia, Oreochromis aureus. Aquaculture, 209: 219-232.

RECEIVED: $18 / 01 / 2018$

ACCEPTED: 25/04/2018

ASSOCIATE EDITOR: Rodrigo do Valle 